\title{
Az okosváros-koncepció kritikai földrajzi vizsgálata - elméleti háttér és lehetséges kutatási irányok
}

\section{A critical geographical analysis of the smart city concept - theoretical background and possible research directions}

\author{
SZALAI ÁDÁM
}

SZALAI Ádám: PhD hallgató, Szegedi Tudományegyetem Természettudományi és Informatikai Kar, Gazdaság-és Társadalomföldrajz Tanszék; 6722 Szeged, Egyetem u. 2., szalaiad@sol.cc.u-szeged.hu; https://orcid.org/0000-0002-8786-0470

KULCSSZAVAK: okos város; okos város kritikák; várospolitika; kritikai városföldrajz

ABSZTRAKT: A városok felgyorsult növekedése, az egyre nagyobb léptékű népességkoncentrációk kialakulása és az ezzel egyidejüleg végbemenő technológiai fejlődés következtében napjainkra a városkutatásban szinte megkerülhetetlen témává vált az ún. okosváros-koncepció. Az okos város fogalma az elmúlt évtizedekben alakult ki, fóként az urbanizáció, a digitális forradalom, a hatékonyabb és fenntarthatóbb városi szolgáltatások és a környezetvédelem iránti társadalmi igényekre adott válaszként. Az infokommunikációs technológiák használata a településfejlesztésben jelentős potenciállal bír, ezért a smart city koncepció egy új fejlődési paradigmaként is értelmezhető.

A tanulmány első részében bemutatom, miképpen magyarázható az okosváros-koncepció, milyen összetevői vannak, a nemzetközi szakirodalomban hogyan definiálják. Ezt követően kitérek arra, hogy bár a városfejlesztési trendek az okos városok felé mutatnak, a koncepció gyakorlati megvalósításának (megvalósíthatóságának) vizsgálatakor a kritikai városföldrajzi megközelítés számos olyan területet azonosít - mint a fejlesztések területi és társadalmi fókusza, a közösségi bevonás, az adatgazdálkodás - amelyek alapvető fontosságúak a sikeres, befogadó és fenntartható okos városok létrehozásához. E kritikai elemzés a jelenleg uralkodó neoliberális várospolitika ismérveivel veti össze az okosváros-koncepció egyes elemeit valamint hiányosságait. A tapasztalatokra építve megfogalmazom, hogy a témában milyen új, eddig feltáratlan kutatási kérdések merülnek fel.

Ádám SZALAI: PhD student, Department of Economic and Social Geography, University of Szeged; Egyetem u. 2., H-6722 Szeged, Hungary; szalaiad@sol.cc.u-szeged.hu; https://orcid.org/ 0000-0002-8786-0470

KEYWORDS: smart cities; smart city critics; urban policy; critical urban geography

ABSTRACT: The smart city concept has recently become a popular topic in urban studies. It can be argued, that the creation of smart cities is a new, 21st century chapter of urban policy and spatial development, dominated by market-oriented, neoliberal ideology. The concept is formed by several stakeholders, such as innovators and investors, policymakers and last but not least smart citizens, who supposedly can discover new ways of living and interacting. It is commonly assumed, that the use of information and communication technologies (ICTs) is the backbone of the smart city idea, but there is no conceptual clarity regarding the concept because of its complexity.

This paper aims to give deeper insights into the theoretical background of smart city, presenting the most important characteristics and critics of the concept, based on an international literature review.

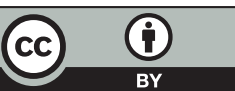


First, I collect and describe the essential components and the most common definitions of the smarty city concept. Afterwards, I put smart cities in the context of neoliberal urban policy, investigating the interests and power relations behind the concept. Furthermore, I identify critical junctures in evolving smart city discourses; these shed light on the issue that the smart city concept cannot be considered as a one-size-fits-all solution to urban problems. In addition, commodification of urban space, surveillance and control of urban life, favouring business-led technological solutions rather than political bargaining and long-term urban planning, might contribute to growing social and territorial disparities.

The critical analysis of the smart city concept raises further research questions about the way the concept can be understood in different geographical contexts, shedding light on the main reasons and barriers to become a smart city. The analysis indicates a need for more empirical research as the broader social and spatial effects of implementing the concept are still largely unexplored, especially in Hungary.

\section{Bevezetés}

Az utóbbi években a városok gazdaságát és szükségleteit sok új kihívás érte. Ilyen a folyamatos gazdasági növekedés, a nemzetközi versenyben való helytállás szükségessége, vagy éppen a városi térségek és városegyüttesek folyamatos növekedése, illetve a területi polarizáció erősödése (Körmendy 2015). A népesség számának emelkedése, az erőforrások véges mennyisége és a növekvő energiafelhasználás miatt egyre inkább előtérbe kerül a legnagyobb népességszámú városok ésszerűbb működésének problémája. E globális léptékủ kihívások ismeretében a nemzetközi városkutatásban felértékelődik a sikeres városfejlesztéshez szükséges intelligens megoldások (pl. távmunka, intelligens közlekedési rendszerek) vizsgálata, hiszen ezek a megoldások a közeljövőben a városi átalakulás legfontosabb összetevői lesznek (Pelton, Singh 2019).

A városi átalakulás egyik vezérszava az elmúlt 15 évben a 'smart city' (okos város), amely nemcsak a tudományos diskurzusokban nyert teret, hanem a közés magánszféra, valamint a média figyelmét is felkeltette. A kifejezés - leegyszerűsített értelmezése szerint - egyrészt az információs és kommunikációs technológiák (IKT) használatára utal a gazdasági fejlődés ösztönzésében, másrészt a szoftveralapú technológiák kiterjedt beágyazására a városi szövetbe, a városi élet átformálása érdekében. Az okos város gazdaságát egyre inkább a technológiai innováció, a kreativitás és a vállalkozói szellem határozza meg. Mindazonáltal az okosváros-modellnek a települések életére, a városfejlesztés gyakorlatára kifejtett hatását mindig az adott földrajzi kontextusban lehet a maga mélységében megérteni (Baji 2017).

Jelen tanulmány fó célja az, hogy érzékeltesse az okos város fejlesztési modelljének sokszínűségét és kritikailag elemezze a 'smart city' koncepció fogalmát több, egymástól eltérő értelmezés bemutatásán keresztül. Ezt a fó célt két specifikus célra bontom: 
- A vonatkozó szakirodalom alapján bemutatom, hogy egyes szerzők milyen tényezők megléte esetén tekintenek egy várost okos városnak. Az okosváros-koncepciójára támaszkodó stratégiai tervezés alapeleme az adottságok feltárása, így a koncepció helyi adaptációjának egyik kihívása, hogy az innováció fogalmát újraértelmezzék (vagyis, hogy az innováció tartalma településspecifikus legyen), és hogy képessé tegyék a városlakókat, vállalkozásokat és más helyi szereplőket a város jövőképének alakítására (Komninos, Pallot, Schaffers 2013).

- Ismertetem a kapcsolódó szakirodalom okosváros-kritikáinak fö pontjait, vagyis azt, hogy az egyes szerzők a koncepció mely elemeit és milyen aspektusból vitatják, milyen hiányosságait emelik ki.

Bár az okosváros-kezdeményezéseket és -technológiai megoldásokat helyi szinten alkalmazzák, terjedésüket erősen befolyásolják a nagyobb területi hatáskörü intézmények és az intézményi, fejlesztési gyakorlatok változásai. Emiatt az okos városok vizsgálatát egy tágabb elméleti keretbe helyezve, a várospolitika recens változásaival (neoliberális fordulattal) együtt tárgyalom, s ennek során rámutatok ezen átfogó várospolitikai változások és az okosváros-koncepció elterjedése közötti összefüggésekre is. Elsőként röviden ismertetem az okosváros-koncepció elméleti hátterét, mozgatórugóit és definícióit. Ezt követően bemutatom, hogy a kritikai városföldrajz szerzői szerint miképpen ágyazódik be az okosváros-koncepció a neoliberális várospolitikai fordulatba. Végül, a tanulmány utolsó részében fogalmazom meg az okosváros-koncepcióval szembeni kritikai észrevételeimet.

\section{Az okos városok kialakulásának mozgatórugói}

Az okosváros-alkalmazások gyakoriságának növekedését, a fogalom elterjedését egyes szerzők a globális városi kihívásokra vezetik vissza (Washburn, Sindhu 2010; Townsend 2013). A téma szempontjából különösen fontos, hogy

- 2007-ben a városlakók aránya világszinten meghaladta az 50\%-ot;

- 2008-ban a hálózatra kapcsolt eszközök száma meghaladta a Föld népességszámát;

- a vezeték nélküli hálózaton keresztül csatlakozó internetfelhasználók száma először haladta meg a vezetéken keresztül csatlakozó felhasználók számát (Townsend 2013).

Az okos városokkal foglalkozó empirikus szakirodalom (Taewo, Pardo 2011; Guedes et al. 2018; Caragliu, Del Bo 2018; Yigitcanlar et al. 2018; Kunzmann 2014) jellemzően három fó tématerület köré csoportosítja az okos városok elterjedését elősegítő mozgatórugókat (1. táblázat). 
1. táblázat: Az okos városok kialakulásának legfőbb mozgatórugói a nemzetközi szakirodalomban Main drivers of the evolution of the smart city concept

\begin{tabular}{ll}
\hline Technológiai fejlödés & Az okosváros-alkalmazások használatát, az egyes városi alrendszerekben \\
& lezajló folyamatok nyomon követését és összekapcsolását az új eszközök \\
& teszik lehetővé. A szenzorhálózatokból leszűrt adatok segítségével az \\
& információáramlás gyorsabbá válik, ami olyan településfejlesztési \\
& beavatkozásokat tesz lehetővé, amelyek javítják a városlakók életminőségét \\
& és a városi életet könnyebbé, kényelmesebbé teszik. \\
Közösségi bevonás a tervezésben & Megáltozik az egyirányú kommunikáció a városvezetés és a lakosság \\
& között. A közösségi döntéshozatalban részt vevő lakosság - a városi \\
& szolgáltatások kedvezményezettjei - megnevezik a megoldandó \\
& problémákat és részt vesznek a városfejlesztésben és -tervezésben, valamint \\
& az adatgyüjtésben a közösségi észlelés ('crowdsensing') útján. Ennek eszközeit \\
& és csatornáit a technológiai fejlődés teremti meg. \\
& Az okosváros-koncepció szerinti fejlesztés új logikát követ. A várost és a \\
& benne zajló folyamatokat komplex rendszerként kezeló szakpolitika a \\
& területi tervezés eszközeivel hajt végre stratégiai szemléletű \\
beavatkozásokat a városi szövetben a városi élet negatív hatásainak \\
minimalizálása érdekében.
\end{tabular}

Forrás: saját szerkesztés

A megfelelö beavatkozások e tématerületek mentén a következő pozitív jövőképet vetítik előre az okos városokban:

- erősödik az innováción alapuló helyi gazdaság (gazdasági fejlődés);

- az okosváros-technológiákhoz nemcsak az elitek, hanem más társadalmi csoportok is csatlakoznak, ami hozzájárul a társadalmi egyenlőtlenségek és a digitális szakadék mérséklődéséhez (társadalmi fejlődés);

- a fenntartható fejlődés alapelvének megfelelően az okos város minimalizálja ökológiai lábnyomát, csökkenti szén-dioxid kibocsátását és növeli a zöldterületek arányát (környezeti fejlődés);

- a városvezetés képes a dinamikus alkalmazkodásra, valós igényeken alapuló beavatkozásokkal kezeli a mindennapi működési kihívásokat (intézményi fejlődés) (Yigitcanlar et al. 2018).

Pelton és Singh (2019) szerint az okos város nemcsak technológiai innováció, hanem olyan folyamat, amely kreatív módon egyesíti a városfejlesztéshez szükséges különböző elemeket (1. ábra).

A mozgatórugók, fontosabb tématerületek és potenciális jövőképek alapján az okosváros-modell a fejlesztési célok keretrendszereként értelmezhetö, amely a technológiai innovációk és az adatfeldolgozás által kínált potenciál kiaknázásával, valamint a közösség szakpolitikába való bevonásával igyekszik meghatározni a városok fejlesztési céljait (2. ábra).

Az okos város komplex modellje a technológia-vezérelt megközelítés helyett a városfejlesztésre fókuszál, az egyes, a városok fejlődése szempontjából releváns célok és fejlesztési alapelvek összessége alkotja az okos város-modell keretrendszerét. 
1. ábra: Az okos város kulcselemei

Key elements of the smart city concept

Városban élök igényeinek kielégítése

- Oktatás, egészségügy, lakáspiac, infrastruktúra, digitális egyenlőség.

Fenntarthatóság, körkörös gazdaság

- Környezeti-klimatikus változásokhoz, az urbanizációhoz és népességnövekedéshez való alkalmazkodás.

Versenyképesség

- A város gazdasági növekedésének elősegítése. Munkahelyteremtő és -megtartó programok.

Okos tervezés és közösségi részvétel

- „Intelligens” adatelemzés. Széleskörü közösségi bevonás. Fiatalok helybentartása.

Infrastruktúra és erőforrások

- Megbízhatóan és költséghatékonyan biztosítani a szolgáltatásokat mind a városi polgárok, mind a vállalkozások számára.

Technológia és mesterséges intelligencia

- A technológiai innovációk használata a közösség igényeinek kielégítésére.

Biztonság

- Védelem a kibertámodások és természeti katasztrófák ellen.

Forrás: Pelton, Singh (2019)

2. ábra: Az okos város-modell keretrendszere

Framework of the smart city model

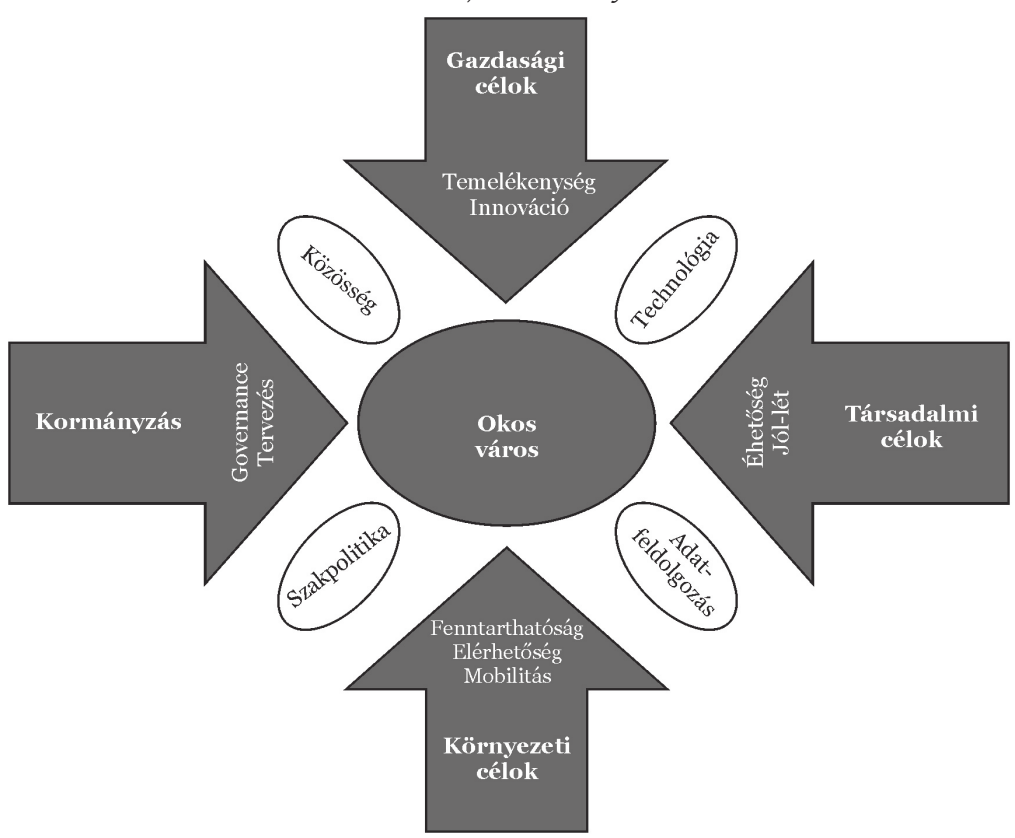

Forrás: saját szerkesztés 


\section{Az okos város definiálása}

Elsőként Lipman és szerzőtársai (1986) utalnak az okos városokra, amelyeket müholdas, száloptikai, mikrohullámú és hagyományos vezetékes hálózatok kötnek össze, s amelyeket tulajdonképpen kommunikációs csomópontoknak tekintenek. A fejlesztési modell a '90-es években vált igazán népszerűvé a szakirodalomban, az információs és kommunikációs technológiák (IKT) és az internet széles körü elterjedésének köszönhetően (Graham, Aurigi 1997). Batty (1990) szerint az információs hálózatok teszik a városokat intelligenssé (Batty 1990). Szingapúr az első város (és egyben ország), amely átfogóan alkalmazta az intelligens város vízióját (Mahizhnan 1999). Az okosváros-koncepció a 2000-es évektől mindinkább teret nyert, azzal párhuzamosan, hogy a fogalom bekerült a technológiai cégek szóhasználatába is.

Mindazonáltal a fogalmi kérdések tisztázását nehezíti, hogy a széleskörű vita ellenére az okos (vagy intelligens?) városoknak nincs konszenzusos definíciója, mivel az okos városok stratégiai tervezése egy egészében feltáratlan és komplex terület (Hollands 2008; Komninos 2011). Következésképpen az okos városhoz számos rokon fogalom köthető (3. ábra). A címkék széles skálája három dimenzióba sorolható: technológia, társadalom és közösség. A fogalmi változatok sokfélesége és a közöttük lévő kapcsolatok tisztázatlansága eredményezi a definíciók gyakori keveredését és bonyolult használatát (Taewo, Pardo 2011).

A fentiekhez szorosan kapcsolódik a kreatív város koncepciója is, amelynek kidolgozója a brit várostervező, Charles Landry volt (Egedy 2017). E szerint napjainkban az ún. kreatív korban élünk, amelyben megváltozott a városok szerepe,

3. ábra: Okos városokhoz kapcsolódó fogalmak

Synonyms of the notion of the smart city

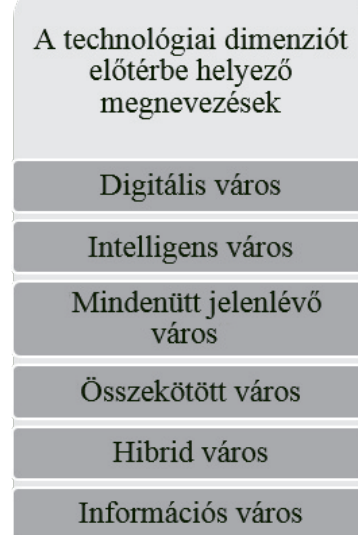

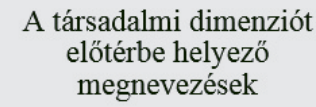

A társadalmi dimenziót előtérbe helyező megnevezések

Kreatív város

Tanuló város

Humánus város

Tudományos város

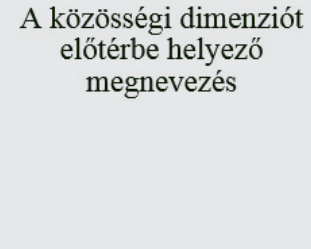

Okos (tervezésbenfejlesztésben) résztvevő közösség 
kommercializálódtak, és akárcsak az áruk, a városok is termékként vannak jelen a piacon. A piaci versenyben azok a nyertesek, akik a kreatív ágazatokban, mint például dizájn, média, film, élen járnak, és akik globális innovációs hálózatokhoz kapcsolódtak (Horváthné Barsi, Lados 2011).

Ehhez képest az intelligens város fogalma más értelmezésben a tudásalapú társadalom (amelyben a tudás és a kreativitás a legfontosabb erőforrás, valamint az emberi és társadalmi tőke a legértékesebb) kontextusában jön létre. E megközelítéssel ért egyet Yigitcanlar (2015) is, aki kiemeli, hogy az információs technológia elősegíti a tudásalapú fejlődést, amelyet a jövő városfejlesztési kulcselemének tekint, ezzel is kiemelve a tudás és városfejlődés közti erősödő kapcsolatrendszert.

Az okos városokról szóló diskurzusokban azonban a technológia szerepe a leghangsúlyosabb, és a megközelítések többségében közös pontnak tekinthető, hogy az infokommunikációs megoldások alkalmazására építenek (Sallai et al. 2018). Az információs és kommunikációs technológiák folyamatos fejlesztéseinek köszönhetően csökken az egyes eszközök használatának költsége. Ilyenek például a mobileszközök, a közösségi média, a felhőszolgáltatások, amelyek mind alkalmasak a növekvő mennyiségű adatok kezelésére, s ezáltal egyre több módszer és eszköz áll rendelkezésre a városban zajló folyamatok vizsgálatára (Mosannenzade, Vettorato 2014). Mivel napjainkban az infokommunikációs eszközök robbanásszerü fejlődésének és elterjedésének következményeképp egyre több eszközt használunk, az internetre kapcsolódott eszközök száma is megsokszorozódik, ezáltal pedig a „dolgok internete" ('internet of things') jelentősen kibővül (Egedy 2017).

Hall (2000) olvasatában az okos város integrálja és folyamatosan monitorozza az összes kritikus infrastruktúra, mint pl. például utak, kommunikációs infrastruktúra, vízvezetékek állapotát, és a folyamatos megfigyelés által képes optimalizálni az erőforrásokkal való gazdálkodást, így polgárai számára a legmagasabb minőségű szolgáltatásokat tudja nyújtani. A hálózatok szerepe meghatározó az okos város üzemeltetésében, e hálózatok a vezetékes és a mobil smart city infrastruktúrán, a nagy teljesítményü IKT-n alapulva biztosítják a szolgáltatásokat a városlakók számára (Lee, Phaal, Lee 2013). Batty et al. (2012) szerint az okos város a „kemény” infrastruktúra (pl. közutak, vasút, közműhálózat elemei) valamint a minőségi és elérhető kommunikációs infrastruktúra szintézise, amely lehetővé teszi a humán tőke növekedését, ami különösen meghatározó a városok versenyképessége szempontjából.

Az okos városok értékét tovább növeli a környezeti szempontok érvényesülése; az okos városban a környezet vonzerőt jelent (Vanolo 2014), ugyanakkor a környezeti szempontok figyelembe vétele az életminőség javulását szolgálja. A polgárok bevonása is kulcsfontosságú az intelligens, fenntartható városfejlesztés olyan formáinak megvalósításában, amelyek a környezetvédelemre és a társadalmi méltányosságra helyezik a hangsúlyt, s nem a piacközpontú városfejlesztést tekintik prioritásnak (Martin, Evans, Karvonen 2018). Ha ugyanis a fejlesztők környezettudatossága jószerivel kizárólag a szén-dioxid mennyiségének csökkenté- 
sére szorítkozik a „tiszta technológia” fejlesztésével és az abból származó invenciók áruba bocsátásával, akkor a környezetvédelmi célok profitvezérelt kiválasztásának eredményeként számos más fontos témát (különösen az ökoszisztéma-szolgáltatások) elhanyagolnak, mert azokat gazdasági szempontból nem tartják vonzónak. Még nagyobb probléma, hogy a szélsőséges mértékü technológiai függőség a globális környezeti problémák megoldása helyett könnyen újratermelheti azokat, az IT eszközök bővülő gyártásával járó fokozott erőforrás-felhasználás és hulladékfelhalmozás révén (Yigitcanlar et al. 2018).

Az egyes megközelítések egyéb kulcsterületeket és témákat is magukba foglalnak a technológia primátusán túl, úgymint a közösséget, a szakpolitikát, a termelékenységet, a fenntarthatóságot, az elérhetőséget, a jólétet, az élhetőséget, a kormányzást. Az Európai Bizottság által megfogalmazott meghatározás szerint az okos városokban az IKT a hatékonyabb erőforrás-felhasználást, a kibocsátáscsökkentést szolgálja, amely az okosabb városi mobilitásban, a hulladék újrahasznosításában és a még hatékonyabb épületenergetikában nyilvánul meg. Ezen túl kiemelt szerepet kap az interaktív és a problémákra, igényekre érzékenyen válaszoló önkormányzati kultúra, a közterek biztonsága és az idősödő népesség igényei is (ec. europa.eu 2018). Caragliu és Del Bo (2018) szerint az okosváros-koncepció népszerüségének fö oka a benne rejlő gazdasági potenciál. Következésképpen az intelligens eszközök alkalmazásán alapuló városi szakpolitika elsődlegesen a gazdasági teljesítményt serkenti, azon kívül minden más hatás a smart city koncepció pozitív externáliájának tekinthető.

Sok az ellentmondás a tekintetben, mely városok tekinthetők okosnak, hogyan válik egy város okossá, s hogy miért is fontos ez tulajdonképpen. Az okos városok kapcsán az alábbi kétségek merülnek fel:

- Az okos városok kutatásának értelmezési kerete nemcsak új, de folyamatosan fejlődik is, s ez ugyan alapot nyújt az okos városok összehasonlításához, ám az egyes városokban a különböző tényezők eltérő súlyúak és jelentőségűek, ami az eredmények sokszínűségével jár az okos városok kutatásában (Chourabi et al. 2012).

- A smart city koncepció alkalmazása gyakran fragmentált, azaz sok esetben csupán néhány alrendszerre vonatkozik. Kérdéses például, hogy egy okos közlekedési rendszerrel bíró város már okos városnak tekinthető-e (Lombardi et al. 2012).

- Még nem ismerjük a mesterséges intelligencia jövőbeli hatását, nem látjuk, milyen szerepe lesz az okos város múködésében (Allam, Dhunny 2019).

- Az olyan kifejezéseket, mint „okos” vagy „intelligens” gyakran használják marketingcélokra, különböző városi digitális alkalmazásokhoz rendelik hozzá őket, ami miatt ezek a kifejezések bizonyos értelemben divatos hívószóként ('buzzword') jelennek meg a várospolitikában (Kourtit, Nijkamp 2012). 
- Az okosváros-koncepció minden feltételének megfelelő várost még nem hoztak létre, mivel működési és finanszírozási nehézségek egyaránt akadályozzák megvalósítását. Az egyetemes értékelési, értelmezési keretek hiánya miatt nehéz átfogóan elemezni az okos városokat (Angelidou 2015).

- Egy további fontos észrevétel szerint a törekvés az okos város létrehozására voltaképpen egy stratégiai jövőkép megalkotását jelenti (Schaffers et al. 2011). A smart city ténylegesen inkább stratégia mintsem realitás (Komninos, Pallot, Schaffers 2013), elképzelés egy olyan város jövőjéről, amely kiaknázza a digitális technológiában és innovációs hálózatokban rejlő lehetőségeket. Az okosváros-koncepciókban foglaltak a legtöbb esetben nem is tartalmaznak azonnal elérhető célokat, inkább hosszú távú stratégiai megközelítéseknek tekinthetők.

\section{Az okosváros-koncepció helye a neoliberális várospolitikai fordulatban}

A kritikai városföldrajz az okosváros-koncepció elterjedését a városi tér neoliberális, piaci szempontokat előtérbe helyező átalakulási folyamatának részeként értelmezi (Grossi, Pianezzi 2017; Vanolo 2015; Hollands 2015; Kitchin 2015; Greenfield, 2013). A neoliberális szemlélet nemcsak az okosváros-fejlesztési elképzelések gyakorlati megvalósításában, hanem azok elméleti hátterének kidolgozásában is egyre nagyobb teret nyer, amit jól mutat az is, hogy az okos várost egyes szerzők olyan címkékkel illetik, mint a „vállalkozó város” vagy a „privát város”(Grossi, Pianezzi 2017).

A neoliberális ideológia a vállalatok fokozott részvételét irányozza elő a közpolitikákban, a piacközpontú szemlélet beépülését a szakpolitika-alkotás minden szintjébe, így a várospolitikába is (Sager 2011). A neoliberalizmus értékrendje szorosan összefonódik a tőkefelhalmozás résztvevőinek, elsősorban a transznacionális nagyvállalatok céljaival, akiknek jól felfogott érdeke a dereguláció, vagyis a gazdasági szabályozási elemek lebontása és a privatizáció, azaz a termelőeszközök magánkézbe helyezése, ezáltal pedig a piaci szereplők előnyben részesítése (Wacquant 2012). A neoliberális keretek között a piac olyan szolgáltatásokat, infrastrukturális és erőforrás-ellátási rendszereket (köztük a lakhatást és a közterek fenntartását) szervez meg és működtet, amelyek addig az állam kezelésében voltak (Cardullo, Kitchin 2018). A tőkeérdekek leghatékonyabb kiszolgálása a legnagyobb profitot hozó területeken realizálható, ahol az agglomerációs előnyök kiaknázásával (a felvevőpiac, a munkaerő és a know-how koncentrációja) erősíthető a gazdasági versenyképesség. Ezek a területek pedig a városok és agglomerációik, amelyek a kapitalizmus és a várospolitika neoliberális átalakulását követően még inkább felértékelődtek.

A kritikai várospolitikai szakirodalom szerzői az 1970-es évek gazdasági válságából és a kapitalizmus átalakulásából eredeztetik, illetve azok következményé- 
nek tekintik a várospolitikai intézményrendszer szerkezetváltását (Brenner 1999; Harvey 1989). A tőke- és gazdasági érdekek növekvő összefonódása, valamint a fokozódó verseny eredményeként a területfejlesztési beavatkozások fó célpontjaivá váltak a városok (Nagy, Izsák 2017), amelyeket az Európai Unió területi politikája is mindinkább előtérbe helyez: a 2008-as Marseille-i Nyilatkozat a funkcionális várostérségeket helyezi a középpontba, míg a 2010-es Toledói Nyilatkozat az integrált városi megújítás fogalmát vezeti be (Salamin 2018).

A vonatkozó szakpolitikák középpontjába a város a tőkefelhalmozás színtereként, illetve eszközeként került, ahol az állam beavatkozásai alapvetően a gazdasági növekedést (versenyképesség javítását) szolgálják (Nagy 2012), a városi teret áruként, pénzben kifejezhető eszközként értelmező, versenyképességi és növekedési rezsim válik uralkodóvá (Pálné Kovács 2008; Ward 2018). Swyngedouw (2002) ezt a megközelítést - amikor a hagyományos redisztributív területi politikát felváltja a kompetitív és növekedésorientált várospolitika - illeti az „új várospolitika” kifejezéssel. Az állam kivonul az egyes társadalmi alrendszerek finanszírozásából és a reprezentatív megoldásokkal kecsegtető PPP ('public-private partnership') beruházások felé fordul. A városi tér revitalizációja a települések funkcióbővítésének, az új munkahelyek teremtésének mozgatórugója, ami biztosítja helyüket a globális munkamegosztásban. Ily módon a városmegújulás csupán egy közvetett cél a növekedés elérésében, a gazdasági teljesítmény előfeltételeként szolgál (Swyngedouw 2002). Habár ez az általános fejlődési modell a különböző városokban igen eltérő formákban fordulhat elő, a projektalapú városfejlesztési beavatkozások alapjaiban változtatják meg a városok eddigi fejlődését, prioritásaik, céljaik és jövőképük alakulását (Swyngedouw 2002). Mindezt tovább erősíti a városi önkormányzatok instabil pénzügyi helyzete, amely arra kényszeríti őket, hogy egyre inkább a magán- és helyi bevételi forrásokra támaszkodjanak (Grossi, Pianezzi 2017). A neoliberális urbanizmust a piaci mechanizmusokon alapuló városi növekedés stratégiájának mintájaként lehet összefoglalóan jellemezni, amely akár a társadalmi igények és a közjavak kárára is felhasználja a profitszerzés spekulatív eszközeit (Cardullo, Kitchin 2018).

E paradigma általánossá válása a profitorientált megközelítés elterjedéséhez és a magas innovációs-technológiai ismeretekkel rendelkező magánszereplők térnyeréséhez vezet. A városi szövetet és a benne lakók életét átformáló új koncepció a smart city, amely innovatív megoldásokat kínál, megpróbál válaszolni a városokat érintő kihívásokra, és ezzel egyidejűleg egyesülnek benne a neoliberális, versenyképességi és a városi tér értékének növelésére irányuló célok. A smart city térhódítása a 2007-2008-as világgazdasági válságra vezethető vissza, amikor a korábban foáramban szereplő, a városokra, mint eladandó termékre fókuszáló kreatív város koncepciója helyett a digitális technológia és annak alkalmazása lett a városfejlesztés kulcseleme, így a smart city elterjedése a várospolitikán belüli paradigmaváltásként is értékelhető (Egedy 2017). 


\section{A smart city koncepció kritikái}

Megosztott a szakirodalom az okosváros-koncepció definiálását és elméleti hátterét övező kérdésekben. Általánosságban elmondható, hogy mind a hazai, mind a nemzetközi szakirodalomban viszonylag kevés a kritikai reflexió a technológiában gyökerező okosváros-fejlesztésekre, hiszen csak az utóbbi néhány évben kezdték el vizsgálni ennek az új városfejlesztési elképzelésnek a hatásait. A kritikai szakirodalom eddig elsősorban az okosváros-fejlesztések előnyeinek egyenlőtlen földrajzi eloszlásával foglalkozott, és a hazai kutatók is a nagyvárosi térségek kedvezményezését emelik ki a vidéki térségekkel szemben, pedig a rurális térségek fejlesztési stratégiáiban szintén alkalmazhatóak a smart city koncepció egyes elemei (Józsa, Kneisz 2019). Összességében azonban még nem élvez jelentős tudományos érdeklődést az a kérdés, hogy az okosváros-modell mentén történő városfejlesztésnek milyen hátrányai, hiányosságai vannak (Kitchin 2015).

Mindazonáltal az okosváros-kutatók több, kritika tárgyát képező témát azonosítottak melyek új kontextusba helyezik az okos városokról való gondolkodást:

- az okosváros-fejlesztések beilleszkednek a neoliberális várospolitikába;

- az egyes városi érdekcsoportok eltérő érdekei ütközhetnek egymással;

- az okosváros-technológiák alkalmazásával bővülő adatgyüjtés befolyásolja a városi élet kontrollját;

- a közösség bevonásának dilemmája;

- az okosváros-koncepció technokrata megközelítése;

- s végül a kérdés, hogy az okosváros-koncepció általános érvényü fejlesztési modellként definiálható-e.

A szakirodalomban legnagyobb súllyal megjelenő irányvonal a neoliberális várospolitika kritikáját fogalmazza meg, különös tekintettel az okosváros-kezdeményezések céljaira és megvalósítási módjaira, valamint a technokrata kormányzás új formáira. A kritikákat tovább ösztönözte, hogy az okos városok piaci szempontú fejlesztése az üzleti célok előtérbe helyezését okozhatja más társadalmi-gazdasági célok rovására, ami a társadalmi polarizáció és egyenlőtlenségek erősödését eredményezheti (Hollands 2015).

Európában az utóbbi néhány évben vált igen népszerűvé „az okossá válás eszméje", különösen miután a smart cityk létrehozása az EU kutatásfejlesztést célzó elképzeléseinek központi témájává vált. A 2007-2013-as fejlesztési ciklusban az Európai Unió 7. kutatási keretprogramja volt a kutatás-fejlesztés fó finanszírozója. Ennek keretében az energiapolitika részét képezte az európai okos városok létrehozásának szándéka, mivel - optimális esetben - az okos városok hozzájárulnak az olyan Európa 2020-as célokhoz, mint üvegházhatású gázok kibocsátásának 20\%-kal történő csökkentése (ec.europa.eu 2019). Kérdéses azonban e célok megvalósulása, valamint az okos városok hozzájárulásának mértéke e célok eléréséhez - mindez csak a ciklus lezárásakor lesz látható. Mindazonáltal kijelenthető, hogy a 2014-2020-as fejlesztési ciklusra szóló, közel 80 milliárd eurós költségveté- 
sű Horizon 2020 innovációs keretprogramon keresztül az EU-s irányelvek továbbra is hatással vannak az európai országok okos város stratégiáira, hiszen ösztönzi azokat a kapcsolódó pénzügyi lehetőségekkel (Vanolo 2014).

A smart city diskurzusban gyakorta felmerül a köz- és magánszektor egyenlötlen szerepének problematikája is. Ahogy Vanolo olaszországi példákon keresztül szemlélteti, több esetben is új „okos város szervezeteket” hoztak létre a köz- és magánszféra szereplői, akik együtt alkotják a „helyi növekedési koalíciót”, amelynek célja kifejezetten a beruházások ösztönzése. Ezek a koalíciók ugyanakkor gyakran nem demokratikus választás útján jönnek létre, inkább arról van szó, hogy a nagyvállalatok PPP konstrukció keretében hajtják végre projektjeiket. Így a smart city diskurzus generálói és terjesztői azok a transznacionális, IKT szektorban működő nagyvállalatok maradnak, amelyek a saját okosváros-koncepciójuk alapján kívánják átalakítani a városokat (Vanolo 2014).

A szenzoroknak köszönhetően a valós idejű rendszerek lehetővé teszik a városi közművek és szolgáltatások hatékony ellenőrzését, a közbiztonság javítását, valamint az esetlegesen bekövetkező gazdasági és környezeti károk hatékony kezelését (Kitchin 2015). A városokat átszövő szenzorhálózat és kamerarendszer azonban a városlakókban azt az érzetet keltheti, hogy megfigyelik őket, hogy valaki vagy valamilyen szervezet közvetlenül gyakorolja a városi élet kontrollját. Az ilyesfajta ellenőrzés ronthatja a szomszédsági viszonyokat és a közösségi élet szabadságát, valamint a személyes kapcsolatokra is negatív hatást fejt ki, ha ezek a technológiák nem a városlakók javát, biztonságát szolgálják, hanem kizárólag a városvezetés és a vállalatok számára készülnek a privát szféra megsértésével és személyes adatok kezelésével, s ez végső soron a demokrácia korlátozásaként is értelmezhető (Greenfield 2013).

Ha az okos városok építése fóként technikai problémaként jelenik meg, olyan paraméterek alapján, amelyeket a városi polgárok nem feltétlenül értenek, és a legtöbb technikai kérdés a nagyvállalatok hatásköre marad, akkor még fontosabb, hogy a lakosság által gyakorolt demokratikus és politikai kontroll biztosított legyen. Swyngedouw (2007) szerint az okosváros-elképzelések szakpolitikai diskurzusok és viták nélkül válnak általános fejlesztési célokká, és ez a folyamat az antidemokratizálódás irányába mutat. E megközelítés veszélye, hogy a várospolitika kizárólag egy univerzális és pusztán a technológiai adaptáción nyugvó modellt jelent (McCann, Ward 2010). A smart city vízióba befektető magánvállalatok „,fetisizálják” a technológia városformáló szerepét, megfelelve a kapitalizmus új szellemének, amely szerint a hatalom és a presztízs növelése a beruházásokon keresztül valósul meg. A beruházásokat végrehajtó vállalkozások ezzel egyidejüleg megítélésüket javítani, társadalmi elfogadottságukat is növelni kívánják (Thrift 2005).

Ebbe a diskurzusba illeszthetők az okos városok létrejöttének útjai vagy generációi (2. táblázat):

Greenfield (2013) kritikája szerint a zöldmezős, sokszor mesterségesen létrehozott, technológiára épült városok csupán a technológiai csúcsvállalatok marke- 
2. táblázat: Az okos városok fejlődésének három generációja Three generations of smart cities

\begin{tabular}{ll}
\hline \multicolumn{1}{c}{ Fejlödési út } & \multicolumn{1}{c}{ Fókusz } \\
\hline Technológiavezérelt & $\begin{array}{l}\text { IT cégek kínálják smart szolgáltatásaikat, tesztelik } \\
\text { technológiáikat }\end{array}$ \\
Városközpontú, technológiaalkalmazó & Életminőséget javító okos fejlesztések \\
Együttes értékteremtés & Inkluzív, együttműködő tervezés és fejlesztés \\
\hline
\end{tabular}

Forrás: Fastcompany.com (2015) alapján saját szerkesztés

tingjét szolgálják. Az ilyen beruházások esetében, mint amelyek a szakirodalomban is leggyakrabban szerepelnek (Songdo Smart City, Masdar, PlanIT Valley) kétséges a beruházók szándéka. Nem komplex módon, az ott élőkkel együtt akarnak tervezni és működtetni, inkább eszközként tekintenek a városra, amelynek müködésébe centralizáltan kívánnak beavatkozni. Greenfield „semmiből épülő” okos városokkal szembeni szkepticizmusát igazolja a PlanIT Valley (Porto, Portugália) projekt sikertelensége, amely a menedzsment és érdekegyeztetés hibái miatt vallott kudarcot. Természetesen nehéz feladat - különösen az ilyen zöldmezős projektek megvalósításakor -valamennyi érintett fél (IT cégek, ingatlanfejlesztők, építészek, pénzügyi befektetők és kormány) érdekeinek összecsiszolása, kiváltképp a pénzügyi források becsatornázását illetően. Habár a PlanIT Valley-nek volt területrendezési terve, és a projekt mögé álltak olyan cégek, mint a Cisco vagy a McLaren, nem sikerült elegendő pénzügyi és humán erőforrást, valamint know-howt koncentrálni ahhoz, hogy teljes városszintű integrált rendszert építsenek ki, amely az új város összes szenzorának adatait feldolgozta, majd - a feldolgozott adatok alapján - működtette volna (smartcityhub.com 2018).

A településfejlesztési hatásokon túl, a konkrét okosváros-projektek és a vállalati viselkedésformák összefüggéseit is érdemes vizsgálni (Greenfield 2013). Az ilyen kutatások ugyanis rávilágíthatnak arra, hogy egy top-down szemléletű technológiai vállalat miképpen próbál adat-és technológiavezérelten beavatkozni a városfejlesztésbe (forbes.com 2013.com). A globális internethálózatot müködtető szolgáltatóknak és a helyi közösségnek eltérö érdekeik lehetnek. A szolgáltatók célja és érdeke a dolgok internetének (azaz a hálózatra kapcsolt eszközök összességének) kiterjesztése, valamint az, hogy az egyén legyen a városi adatok alapegysége. A tevékenységeikből gyüjtött adatok jelentik a „város okosságát”, és a város ezen adatok integrált kezelése által képes működtetni alrendszereit (forbes.com 2013.com). Ezzel szemben a helyi közösség számára előbbre valók más tényezők, például a szubjektív jóllét, alapszolgáltatásokhoz való hozzáférés biztonsága.

A „technológia mindent megold” ideája védi a technokrata megközelítést a kritikáktól, ugyanakkor erősíti azt a nézetet, amely szerint a technológiai hálózatok és elektronizált kormányzati gyakorlatok önmagukban is jobb városokat teremtenek, függetlenül a helyi társadalomtól, a technológiai fejlesztések természetétől, valamint a nagy mennyiségü adat rendszerezésének, hasznosításának nehézségeitől egyaránt. Igencsak kérdéses, hogy a mindent számszerüsíteni kívá- 
nó, a városi folyamatokat indikátorokban mérő városvezetési gyakorlat uniformizálható-e. A városok értékelését matematikai-statisztikai módszerekkel végző kutatók erre tesznek kísérletet az okos városok fejlettségét kvantitatív szemszögből vizsgáló kutatásokkal, amelyek Giffinger (2007) tanulmányát veszik alapul, amely hat települési alrendszert értékel 74 különböző indikátor vizsgálatával. Ennél több alapmutató esetében főkomponens-elemzéssel lehet a városok teljesítményének összehasonlíthatóságát javítani (Nagy, Sebestyénné Szép, Szendi 2018). Az alapstatisztikákból, mint például az egy főre jutó GDP, az online tranzakciókat használó lakosság aránya vagy a városi zöldfelületek aránya, egyes területeken kiszámolható a városok teljesítménye. A statisztikai alapú okosváros-elemzés lehetővé teszi a megismételt elemzést, illetve a hazai és nemzetközi összehasonlítást (Nagy, Sebestyénné Szép, Szendi, 2018). Az adatok forrása és elérhetősége azonban nagyban meghatározza a vizsgálatok kimenetét, többnyire EU-s illetve nemzeti statisztikákról van szó. A helyi szintủ okosváros-beavatkozások sikerességének, a városok „okosságának” kvantitatív szempontú mérését nagyban elősegítené, ha a helyi adatok szabványosítva és transzparensen jelennének meg. Jelenleg azonban a városok csekély mértékben élnek a helyi lakosoktól származó adatok begyüjtésével és felhasználásával. Erre lehet alkalmas a már említett közösségi érzékelés (crowdsensing), amely azon alapszik, hogy a városban élők mobiltelefonjaik segítségével (amelyek számos érzékelővel, szenzorral bírnak) saját maguk szolgáltatnak adatokat. Ez a módszer egy elosztott adatgyüjtési megoldás, amely a felhasználók önkéntes adatszolgáltatásán alapul: hibabejelentések, online szavazások, parkolók helyzetének bejelentése stb. (Vida, Fehér 2016). Még ezen adatok birtokában is kétséges, hogy azonnal megbecsülhetők-e a fejlesztések által előidézett hatások; a legfontosabb kérdés mégis az, hogy mért adatokból leszűrt információk, illetve a döntéshozatalt kísérő diskurzusok miképpen azonosítják az adott település problémáit, illetve hogyan tervezik meg az egyes okosváros-megoldásokat. Másként fogalmazva: az okos várossá válás a hatalomtechnika és fejlesztési források lehívásának eszköze, vagy a település stratégiai szemléletű jövőképe?

Az okosváros-fejlesztésekkel kapcsolatos további kritika szerint a smart city koncepció egyes, számukra hasznos elemeit a beruházók, döntéshozók, helyi vezetők kiemelik, és ezzel átalakítják az eredeti koncepciót. Az okosváros-megközelítés kritikai szemléletű vizsgálatának lényege szerint a smart city koncepciót sokszor általános értelemben vett receptnek tekintik, amivel megoldani vélnek városi problémákat. Több kutató (Greenfield 2013; Kitchin 2014; Söderström, Paasche, Klauser 2014; Hollands 2015) úgy véli, hogy a technokrata városfejlesztés mellett érvelők közös álláspontja az a téves következtetés, hogy az okos város kulcsrakész, mindenütt egységesen működő megoldásokat kínál. Ezzel szemben a városok sokkal inkább olyan specifikus helyek a földrajzi térben, amelyek egy jól meghatározott földrajzi-társadalmi környezet termékei, ugyanakkor e helyeket a bennük élők is folyamatosan formálják. A városban való létezés ugyanis - az egy- 
re kiterjedtebb IKT használat által generált, virtuális térben végzett tevékenységek ellenére - nem választható el a város fizikai valóságától.

\section{Összefoglalás}

Tanulmányomban a városkutatásban és -politikában egyre inkább előtérbe kerülő „okos város” fejlesztési modell koncepcionális elemeinek és kritikus területeinek feltárását tűztem ki célul. A definíciós kérdések tisztázásán túl kritikai szemszögből vizsgáltam meg az okos város fogalmával kapcsolatban általános érvényünek tekintett alapvetéseket, bemutattam az okosváros-koncepció hátrányait, hiányosságait.

A szakirodalom elemzése rávilágított arra, hogy az okos város jelentése sokrétü, a fogalom többféleképpen értelmezhető. A magyarországi kutatóknak is fontos tisztázniuk, hogy saját földrajzi kontextusukban hogyan értelmezik és elemzik az okos városokat. A legelemibb meghatározás szerint az okos városban kulcsfontosságú szerepe van az infokommunikációs technológiák használatának az életminőség javítása és a gazdasági fejlettség elérése érdekében (Mahizhnan 1999), s ezzel függ össze az a kérdés is, hogy e technológiák hogyan hatnak a városok lakóira, közösségeire. Az okosváros-kezdeményezések - akárcsak a fogalom magyarázata maga - erősen függ a lokális erőforrásoktól, városvezetési attitüdöktől, ezért az okosváros-projektek gyakorlati megvalósítása és végrehajtása is igényli a koncepció helyi viszonyokhoz való igazítását. Csak a helyi viszonyok ismeretében értékelhető az adott város „okosságának” mértéke, a város teljesítménye az egyes alrendszerek átalakításában. Az okos város fogalma mellett több más elnevezés, fogalom (például kreatív, intelligens, digitális város) is definiálja a jövő városát, amelyek gyakran átfedésben vannak, s nem minden esetben különböznek egymástól. Míg például a kreatív város koncepciója inkább a társadalmi-gazdasági dimenziókat emeli ki (Egedy 2017), addig az okos városban a technológia és annak városi életre gyakorolt hatása kerül előtérbe.

Amennyiben az okosváros-koncepcióra komplex modellként tekintünk - amely egyesíti a településfejlesztés során felmerülő legfontosabb célokat (lásd 2. ábra) -, akkor az okos várost nem a településekre aggatott címkének tekintjük, amely konkrét beruházásokban ölt testet, hanem a városfejlesztéshez és -üzemeltetéshez kapcsolódó attitűdnek, módszertani megközelítésnek.

Alapvető kérdés, hogy a mutatókon alapuló városkutatás képes-e a várospolitika szintjére eljutni és a konkrét intézkedéseket alakítani. A statisztika nem mond arról semmit, hogy helyben milyen szereplők vesznek részt az okosvárosfejlesztésekben, milyen viták zajlanak, milyen alkuk köttetnek helyi szinten, amelyek mind formálják a települések smart city jövőképét. Ez rávilágít az okos városok mérhetőségének bonyolultságára, nem létezik ugyanis egy általánosan elfogadott, univerzálisan felhasználható mérési modell. 
Az okos város átfogó fogalmának megalkotása, a tudományos és elméleti ismeretek elmélyítése mind a kutatók, mind gyakorlati szakemberek számára erőforrásként szolgál, a kutatás és a gyakorlati szakértelem közötti híd építésében, valamint a tudományos alapokon nyugvó városfejlesztésben egyaránt. Ezért is elengedhetetlen a jövőben a társadalomtudomány és az informatika együttműködése (Baji 2017).

A sikeres okos városok megteremtésének elengedhetetlen feltétele a köz- és magánérdekek közötti ellentétek feloldása és a közösség bevonására támaszkodó, helyspecifikus megoldásokat kereső településfejlesztés. A tanulmányban bemutatott top-down tervezési elvü, technokrata modell ugyanakkor tovább erősíti a neoliberális versenyorientált szemléletet, amely torz, függőséget eredményező struktúrákhoz vezethet, a fogyasztásorientált versenyképesség növelését helyezi előtérbe, amelyben helyi szereplők kiszolgáltatottak a külső piaci szereplőknek. A kritikákra adott helyes válaszok közé tartozik a városlakók informálása is annak érdekében, hogy megértsék, saját városuk miért és miképpen kíván „okossá” válni. A technológia által kínált vívmányok etikus felhasználása alkalmas arra, hogy a döntéshozók és a lakosság között erősítse a bizalmat úgy, hogy a városban élöket bevonják a fejlesztési folyamatokba és az adatszolgáltatásba.

Az okos városok létrehozása és fejlesztése a várospolitika és településfejlesztés új, 21. századi fejezete. Egy olyan új eszközt jelent, amelynek segítségével a vállalatok és politikai döntéshozók még jobban kiterjeszthetik befolyásukat. Vagy épp ellenkezőleg: egy olyan reformparadigma, amelyre alapulva a 21. századi városok épülnek. Azt, hogy melyik forgatókönyv érvényesül, számottevően befolyásolja, hogy adott település milyen fejlődési utat választ, és miképpen kezeli a kritikai városföldrajz által feltárt kihívásokat.

\section{Jövőbeli kutatási irányok}

Az okos városok kutatása viszonylag korai szakaszban van úgy a fogalmi fejlődés, mint a gyakorlatban megvalósult beruházásokat vizsgáló empirikus kutatások tekintetében. További kutatásokra van szükség ahhoz, hogy az okosváros-modell megvalósulásának érdekviszonyait, hatásait értékelni tudjuk.

A hálózatra kapcsolt eszközök számának további drasztikus növekedése, az online közösségi szolgáltatások bővülő használata és az internetes tér mind nagyobb léptékủ terjedése az adatok felhasználásának biztonsági kérdéseit veti fel. A felhasználók által megadott adatok kezelésének és felhasználásának dilemmája az elkövetkezendő kutatások fontos területe.

A további vizsgálatok másik fontos törekvése lehet annak megértése, hogy a magyarországi viszonyok között az okosváros-fejlődés miképpen megy végbe, hogyan értelmezik az egyes szereplők ezt a koncepciót. Fontos kérdés, hogy Magyarországon kik az okosváros-projektek felelősei, milyen szakmai viták és érdekviszonyok 
egyeztetésén keresztül történik a projektek megvalósítása. Tekintettel arra, hogy az okosváros-koncepció napjainkban nemcsak a tudományos, hanem a szakpolitikai, közéleti diskurzusokban is fontos téma, és figyelembe véve, hogy a városfejlesztésre az EU-s és a magyar kormányzati szinten is nagy összegű forrásokat rendelnek, a jövőben kulcsfontosságú a hazai fejlesztéspolitikai viszonyok feltárása.

\section{Köszönetnyilvánítás}

A kutatás Az Innovációs és Technológiai Minisztérium ÚNKP-19-3-SZTE-273 kódszámú Új Nemzeti Kiválóság Programjának szakmai támogatásával készült.

\section{Irodalom}

Allam, Z., Dhunny, Z.A. (2019): On big data, artificial intelligence and smart cities. Cities, 89., 80-91. https://doi.org/10.1016/j.cities.2019.01.032

Angelidou, M. (2015): A conjuncture of four forces. Cities, 47., 95-106. https://doi.org/10.1016/j.cities.2015.05.004

Baji P. (2017): Okos városok és alrendszereik - Kihívások a jövő városkutatói számára? Tér és Társadalom, 1., 89-105. https://doi.org/10.17649/TET.31.1.2807

Batty, M. (1990): Intelligent cities: using information networks to gain competitive advantage. Environment and Planning B: Planning and Design, 3., 247-256. https://doi.org/10.1068/b170247

Batty, M., Axhausen, K., Fosca, G., Pozdnoukhov, A., Bazzani, A., Wachowicz, M., Ouzounis, G., Portugali, Y. (2012): Smart cities of the future. The European Physical Journal Special Topics, 214., 481-518. https://doi.org/10.1140/epjst/e2012-01703-3

Brenner, N. (1999): Globalisation as Reterritorialisation: The Re-scaling of Urban Governance in the European Union. Urban Studies, 3., 431-451. https://doi.org/10.1080/0042098993466

Caragliu, A., Del Bo, C.F. (2018): Smart innovative cities: The impact of Smart City policies on urban innovation. Technological Forecasting and Social Change, 142., 373-383. https://doi.org/10.1016/ j.techfore.2018.07.022

Cardullo, P., Kitchin, R. (2018): Smart urbanism and smart citizenship: The neoliberal logic of 'citizenfocused' smart cities in Europe. Environment and Planning: Politics and Space, 5., 813-830. https:// doi.org/10.1177/0263774X18806508

Chourabi H., Taewoo, N., Walker, S., Gil-García, J.R., Mellouli, S., Nahon, K., Pardo, T.A., Scholl, H.J. (2012): Understanding Smart Cities: An Integrative Framework. Paper presented at the Proceedings of the 45th International Conference on System Sciences, Hawaii https://doi.org/10.1109/HICSS.2012.615

Egedy T. (2017): Városfejlesztési paradigmák az új évtizedben - A kreatív és az okos város. Földrajzi Közlemények, 3., 254-262.

Graham S., Aurigi A. (1997): Urbanising cyberspace? City, 2., 18-39. https://doi.org/10.1080/13604819708900051 Giffinger, R., Pichler-Milanovic, N. (2007): Smart Cities: Ranking of European Medium-Sized Cities. Vienna University of Technology, University of Ljubljana and Delft University of Technology http:// www.smart-cities.eu/download/city_ranking_final.pdf (Letöltés: 2019. 06. 05.)

Greenfield, A. (2013): Against the smart city. Do projects

Grossi, G., Pianezzi, D. (2017): Utopia or neoliberal ideology? Cities, 69., 79-85. https://doi.org/ 10.1016/j.cities.2017.07.012

Guedes, A.L.A., Alvarenga, J.C., Goulart, M.D.S.S., Rodriguez, M. V. R., Periera Soares, C.A. (2018): Smart Cities: The Main Drivers for Increasing the Intelligence of Cities. Sustainability, MDPI, Open Access Journal, 10., 1-19. https://doi.org/10.3390/su10093121 
Józsa V., Kneisz I. (2019): Okos valóság Magyarországon? Okos programok megvalósításának esélyei Miskolcon és a magyar-szlovák határ menti térségben. Tér és Társadalom, 1., 66-82. https:// doi.org/10.17649/TET.33.1.3099

Hall, R.E. (2000): The Vision of A Smart City. Paper presented at the 2nd International Life Extension Technology Workshop, September 28. 2000. Paris, France. https://www.osti.gov/servlets/ purl/773961/ (Letöltés: 2019. 06. 01)

Harvey, D. (1989): From managerialism to entrepreneurialism: the transformation of urban governance under late capitalism. Geografiska Annaler, 1., 3-17. https://doi.org/10.1080/04353684.1989.11879583

Horváthné Barsi B., Lados M. (2011): Smart cities tanulmány. MTA RKK Nyugat-magyarországi Tudományos Intézet, Győr http://www.rkk.hu/rkk/news/2011/smart_cities_tanulmany_IBM_RKK.pdf (Letöltés: 2019. 06. 01.)

Hollands, R. G. (2008): Will the real smart city stand up: Creative, progressive, or just entrepreneurial? City, 3., 302-320. http://dx.doi.org/10.1080/13604810802479126

Hollands, R.G. (2015): Critical interventions into the corporate smart city. Cambridge Journal of Regions, Economy and Society, 8., 61-77. https://doi.org/10.1093/cjres/rsu011

Kitchin, R. (2015): Making sense of smart cities: addressing present shortcomings. Cambridge Journal of Regions, Economy and Society, 8., 131-136. https://doi.org/10.1093/cjres/rsu027

Komninos, N. (2011): Intelligent cities: variable geometries of spatial intelligence. Intelligent Buildings International, 3., 172-188. https://doi.org/10.1080/17508975.2011.579339

Komninos, N., Pallot, M., Schaffers, H. (2013): Special issue on smart cities and the future internetin Europe, Journal of the Knowledge Economy, 4., 119-134. https://doi.org/10.1007/s13132-012-0083-x

Kourtit, K., Nijkamp, P. (2012): Smart cities in the innovation age. The European Journal of Social Science Research, 2., 93-95. https://doi.org/10.1080/13511610.2012.660331

Körmendy, I. (2015): Presidents foreword. In: Salamin, G. (szerk.): Cities in action reflecting global economic challenges and technological trends with special reference to the smart city concept. Magyar Urbanisztikai Társaság, Budapest, 6-7.

Kunzmann, K. R. (2014): New paradigm of urban development. Crios, 1., 9-20. https://doi.org/ $10.7373 / 77140$

Landry, C., Bianchini, F. (1995): The creative city. Demos, London

Lee, J.H., Phaal, R., Lee, S. (2013): An Integrated Service-device-technology: Roadmap for Smart City Development. Technological Forecasting and Social Change, 2., 286-306. https://doi.org/10.1016/ j.techfore.2012.09.020

Lipman, A. D. (1986): Teleports and the intelligent city. Dow Jones - Irwin, Homewood

Lombardi P., Giordano, S., Caragliu, A., Del Bo C., Deakin, M., Nijkamp, P., Kourtit, K., Farouh, H. (2012): An advanced triple-helix network model for smart cities performance. Research Memorandum 45. https://doi.org/10.4018/978-1-61350-453-6.ch004

Mahizhnan, A. (1999): Smart cities: the Singapore case. Cities, 16.,13-18. https://doi.org/10.1016/ S0264-2751(98)00050-X

Martin, CJ., Evans, J., Karvonen, A. (2018): Smart and sustainable? Five tensions in the visions and practices of the smart- sustainable city in Europe and North America. Technological Forecasting and Social Change, 133., 269-278. https://doi.org/10.1016/j.techfore.2018.01.005

McCann, E., Ward, K. (2010): Relationality/territoriality: Toward a conceptualization of cities in the world. Geoforum, 2.,175-184. https://doi.org/10.1016/j.geoforum.2009.06.006

Mosannenzade, F., Vettorato, D. (2014): Defining smart city. A conceptual framework based on keyword analysis. Eighth International Conference INPUT Smart City - Planning for Energy, Transportation and Sustainability of the Urban System. https://doi.org/10.6092/1970-9870/2523

Nagy E. (2012): Verseny vagy kiegyenlítés? Az európai várospolitika neoliberális fordulata és a helyi tervezési-fejlesztési gyakorlatok „projektesítése”. In: Pál V. (szerk.): A társadalomföldrajz lokális és globális kérdései. SZTE TTIK Gazdaság- és Társadalomföldrajz Tanszék, Szeged, 54-67.

Nagy E., Izsák É. (2017): A városi gazdaság - (újra)értelmezési lehetőségek a gazdaságföldrajz oktatásához. Földrajzi Közlemények, 3., 246-253.

Nagy Z., Szendi D., Sebestyénné Szép T. (2018): Smart cityk teljesítménye a visegrádi országokban. Erdélyi Társadalom, 1., 59-82. https://doi.org/10.17177/77171.208 
Pálné Kovács I. (2008): Az új várospolitika kormányzási filozófiája. Tér és Társadalom, 1., 45-57. https://doi.org/10.17649/TET.22.1.1155

Pelton, J., Singh, I. (2019): Smart Cities of Today and Tomorrow. Better Infrastructure, Technology and Security. Springer

Sager, T. (2011): Neo-liberal urban planning policies: A literature survey 1990-2010. Progress in Planning, 4.,147-199. https://doi.org/10.1016/j.progress.2011.09.001

Salamin G. (2018): A földrajzi tér alakitásának európaizálódása. Doktori értekezés. Szent István Egyetem, Enyedi György Regionális Tudományok Doktori Iskola, Gödöllő

Sallai Gy., Bakonyi P., Hanák P., Henk T., Kovács K., Nemeslaki A., Nyikos Gy., Orbók Á., Vida R. (2018): Az okos város (Smart city). Dialóg Campus Kiadó, Budapest

Schaffers, H., Komninos, N., Pallot, M., Trousse, B., (2011): Smart Cities and the Future Internet: Towards Cooperation Frameworks for Open Innovation. In.: Domingue, J. et al. (eds): The Future Internet. Springer, Berlin, Heidelberg, 431-446. https://doi.org/10.1007/978-3-642-20898-0_31

Söderström, O., Paasche, T., Klauser, F (2014): Smart cities as corporate storytelling. City, 3., 307-320. https://doi.org/10.1080/13604813.2014.906716

Swyngedouw, E. (2002): Neoliberal Urbanization in Europe: Large-Scale Urban Development Projects and the New Urban Policy. Antipode 3., 542-577. https://doi.org/10.1111/1467-8330.00254

Swyngedouw, E. (2007): Impossible 'sustainability' and the postpolitical condition. In: Krueger, R., Gibbs, D. (eds.): The Sustainable Development Paradox: Urban Political Economy in the United States and Europe. Guilford Press, New York, 13-40. https://doi.org/10.1007/978-90-481-3106-8_11

Taewo, B., Pardo, T. (2011): Conceptualizing Smart City with Dimensions of Technology, People, and Institutions. Proceedings of the 12th Annual International Conference on Digital Government Research, https://doi.org/10.1145/2037556.2037602

Thrift, N. (2005): Knowing Capitalism. Sage, London

Townsend, A. (2013): Smart cities: Big data, civic hackers, and the quest for a new utopia. WW Norton \& Company

Yigitcanlar, T. (2015): Smart cities: An effective urban development and management model? Australian Planner, 52., 27-34. https://doi.org/10.1080/07293682.2015.1019752

Yigitcanlar, T., Kamruzzaman, Md., Buys, L., Ioppolo, G., Marques, J., Da Costa, E.M., Yun, J.J. (2018): Understanding 'smart cities': Intertwining development drivers with desired outcomes in a multidimensional framework. Cities, 81., 145-160. https://doi.org/10.1016/j.cities.2018.04.003

Vanolo, A. (2014): Smartmentality: The Smart City as Disciplinary Strategy. Urban Studies, 51., 883-898. https://doi.org/10.1177/0042098013494427

Vanolo, A. (2015): Urban Neoliberalism. In: Wright, J. D (eds): International Encyclopedia of the Social \& Behavioral Sciences, Elsevier, 846-853.

Vida R., Fehér G. (2016): Infrastrukturális vagy közösségi érzékelés az okos városokban? Híradástechnika, 1. 47-53.

Wacquant, L. (2012): Három lépés a létező neoliberalizmus történeti antropológiája felé. Fordulat, 18., 10-30. http://www.epa.hu/02100/02121/00016/pdf/EPA02121_fordulat_18.pdf (Letöltés: 2019. 06.09.)

Ward, K. (2018): Urban redevelopment policies on the move: Rethinking the Geographies of Comparison, Exchange and Learning. International Journal of Urban and Regional Research, 42., 666-683. https://doi.org/10.1111/1468-2427.12604

Washburn D., Sindhu U., Balaouras S., Dines R. A., Hayes N. M., Nelson, L. E. (2010): Helping CIOs Understand "Smart City”. Initiatives: Defining the Smart City, Its Drivers, and the Role of the CIO. - Forrester Research Inc., Cambridge, MA. 17. https://c3328005.r5.cf0.rackcdn.com/ 73efa931-ofac-4e28-ae77-8e58ebf74aa6.pdf (Letöltés: 2019. 06.09.) 


\section{Egyéb források}

https://ec.europa.eu/programmes/horizon2020/en/what-horizon-2020 (Letöltés: 2019. 06. 01.) https:// www.fastcompany.com/3047795/the-3-generations-of-smart-cities (Letöltés: 2019. 06. 06.) https://www.forbes.com/sites/danielnyegriffiths/2013/12/02/city-cynic-against-the-smartcity-by-adam-greenfield-review/\#12d6eaf43b19 (Letöltés: 2019.06.17.)

https://smartcityhub.com/governance-economy/planit-valley-the-smartest-city-never-been-built/ (Letöltés: 2019. 06. 10.)

https://ec.europa.eu/info/eu-regional-and-urban-development/topics/cities-and-urban-development/city-initiatives/smart-cities_en (Letöltés:2019.12. 09.) 